\title{
Screening of traditional South African leafy vegetables for specific anti-nutritional factors before and after processing
}

\author{
Humaira ESSACK ${ }^{1 *}$, Bharti ODHAV ${ }^{1}$, John Jason MELLEM ${ }^{1}$
}

\begin{abstract}
This study investigated the effect of processing on anti-nutritional factors of thirteen traditional leafy vegetables collected in Kwa Zulu-Natal, South Africa. The aim was to determine whether processing reduced anti-nutrient levels of leafy vegetables. The vegetables were boiled in a plant-to-distilled water ratio of $1: 4(\mathrm{w} / \mathrm{v})$ at $97^{\circ} \mathrm{C}$ for a time period of 5 and $15 \mathrm{~min}$. The vegetables studied were: Amaranthus dubius, Amaranthus hybridus, Asystasia gangetica, Bidens pilosa, Ceratotheca triloba, Chenopodium album, Emex australis, Galinsoga parviflora, Guilleminea densa, Momordica balsamina, Oxygonum sinuatum, Physalis viscosa and Solanum nigrum. From this study, it was determined that non processed samples contained anti-nutrients such as tannins, phytic acid, alkaloids, oxalic acid, and cyanogenic glycoside. Both boiling parameters were effective in reducing the tannin, phytic acid, alkaloid, oxalic acid and cyanogenic glycoside contents of all 13 traditional leafy vegetables. The results of this study provide evidence that the local traditional leafy vegetables which the population is so reliant upon, are important contributors to micronutrient malnutrition in developing countries and can be minimized through common boiling methods for a minimum of 5 and maximum of 15 minutes.
\end{abstract}

Keywords: traditional leafy vegetables; tannins; phytic acid; alkaloid; oxalic acid; cyanogenic glycoside.

Practical Application: Minimization of anti-nutrients using boiling at different time periods.

\section{Introduction}

Nutrition is of great importance especially when a plant or vegetable is being utilized as a source of food. It is imperative to note that endogenous toxic factors within the plant or vegetable can influence the nutrients present. These toxic factors are known as anti-nutrients. Anti-nutrients can be defined as chemicals which are present within the plant to protect the plant as a defence mechanism and aid in other biological functions. They reduce the ability of nutrients such as minerals, vitamins and even proteins within the plant material. This, in turn, affects the nutritional value of these plants. Anti-nutrients comprise of amino acids to proteins, simple amines to alkaloids, glycosides and phenolic compounds. When a plant food is consumed as a nutritional source, along with this, anti-nutrients are consumed and pose a health risk to the consumer (Ugwu \& Oranye, 2006). In sub-Saharan Africa, most of the population live in rural regions. The World Health Organization (WHO) have stated that chronic nutrition deficiency affects 200 million of the sub-Saharan population, which is equivalent to $42 \%$ of the population. The sub-Saharan population is known to have a prevalence in disease. This could be attributed to many factors such as diet changes or environmental factors. Based on FAO reports, about 1 billion people especially in developing countries depend on edible wild plants in their diets. Some of these plants are not only edible, but also have medicinal uses (Unuofin et al., 2017). Due to inaccessibility of resources, the population's nutrition, is sourced from local cereals and plant foods. The staple food in sub-Saharan Africa is based on a diet containing cereals, which are low in micronutrients. Therefore, the daily micronutrient requirements are obtained through traditional leafy vegetable consumption. Traditional leafy vegetables are inexpensive and easily accessible (Omotoso, 2006). Traditional leafy vegetables are also easy to cook, provide roughage and are rich in vitamins and minerals (Lin et al., 2011). Traditional leafy vegetables grow wildly, do not require formal cultivation and can provide high nutrition for poor communities where malnutrition is rife (World Health Organization, 1982). A summary of the traditional leafy vegetables used in the study are depicted in Table 1 (Hutchings et al., 1996). Traditional leafy vegetables are plentiful in South Africa and are known to contain anti-nutrients such as glycosides, oxalic acid, alkaloids and hydrocyanic acid. The presence of anti-nutrients indicates that the evaluation of anti-nutritional factors is therefore necessary (Hutchings et al., 1996). Many workers, (Odhav et al., 2007) have reported the nutritive value of traditional leafy vegetables, however, the anti-nutritive values have not been explored.

Tannins are identified as plant polyphenols that are capable of forming complexes with metals ions and macro-molecules like proteins and polysaccharides. Tannins affect the nutritional value of food products by chelating metals like iron and zinc and reducing the absorption of these nutrients as well as forming complexes with protein thereby inhibiting their digestion and absorption (Olawoye et al., 2017). Tannins are responsible for a protein deficiency syndrome known in Sub-Saharan Africa as 
'Kwashiorkor'. Tannins are responsible for a decrease in growth rate as well as a non-palatable taste. Phytic acid is the major phosphorous storage compound in traditional leafy vegetables. Phytic acid has been recorded to inhibit the absorption of minerals and reduce the bioavailability of metal ions like zinc and iron as well as affect protein and starch digestion. A phytic acid intake of 4-9 mg/100g decreases iron absorption in humans by 4-5 fold. Too much of a phytate rich diet is associated with nutritional diseases such as rickets and osteomalacia in children and adults (Unuofin et al., 2017). Alkaloids are basic nitrogenous compounds produced as metabolites that cause biological effects based on consumption. They occur quite often as a mixture of compounds of related structure. They are found in about $15-20 \%$ of vascular plants, in seeds, leaves, roots, bark etc. They are classified into three groups. True alkaloids (e.g. Pyridine), are heterocyclic nitrogenous bases derived from amino acids toxic to humans and animals, e.g. tobacco and nicotine. Pseudo alkaloids (e.g. Purine alkaloids), are heterocyclic nitrogenous bases and their precursors are not amino acids. They are less toxic than true alkaloids, e.g. caffeine in coffee. Protoalkaloids are basic amines derived from amino acids but the nitrogen is not heterocyclic, e.g. capsaicin in hot peppers. A consumption of high tropane alkaloids can cause rapid heartbeat, paralysis and in fatal cases, death (Velisek, 2014). Other toxic action includes disruption of the cell membrane in the gastrointestinal tract (Unuofin et al., 2017). Oxalic acid exists in many leafy vegetables and plant foods. Depending on species, oxalic acid can occur as soluble salts of potassium and sodium or as insoluble salts of calcium, magnesium or iron or it can occur as a combination of soluble and insoluble salts. This forms strong chelates with dietary calcium inhibiting its absorption. (Akwaowo et al., 2000). It's well known that oxalic acid and its salts can have a deleterious effect on human nutrition and health, mostly by decreasing calcium absorption and aiding the formation of kidney stones (Olawoye et al., 2017).

There are many traditional leafy vegetables which are known to have a rich source in micro and macro nutrients, however, their anti-nutritional factors are unknown. Due to the high levels of macro and micro nutrient malnutrition amongst developing countries the need for anti-nutrient testing and ways to reduce them is in great demand.

Different processing techniques are often utilized in order to reduce anti-nutritional factors (Embaby, 2010). Some processing techniques are performed on household level or domestically and others are performed on a larger scale in industry (Raes et al., 2014). Cooking is a common form of processing in plants that are consumed as a food source. Cooking causes changes in the phytochemistry of the traditional leafy vegetable affecting its bioaccessability and health benefit properties. The degree of these changes depend largely on the cooking methods as well as the traditional leafy vegetable (Odhav et al., 2007).

The proposed research initiative was to conduct a preliminary assessment of the anti-nutritional factors from an array of selected indigenous and underutilized South African traditional leafy vegetables and the effective processing time to minimize these anti-nutritional factors with a view to promote their utilization and contribute to the socio-economic development of the people living in areas where these plants are found.

\section{Materials and methods}

\subsection{Sample collection and preparation}

Anti-nutritional analyses (tannins, phytic acid, oxalic acid, alkaloids and cyanogenic glycoside) were conducted using the raw leaves and boiled leaves of thirteen traditional leafy vegetables. Table 1 indicates a brief overview of the traditional leafy vegetables used in the study. The plants were identified and sourced from general farm land during the months of January to March in Durban, Kwa-Zulu Natal, South Africa. Voucher specimens were housed in Ward Herbarium, University of Kwa-Zulu Natal, Durban, South Africa. Biodata on the plants are listed in Table 1 (Hutchings et al., 1996). The leaves were carefully inspected and damaged or infected leaves were discarded, as the collection period for the samples were during a period of rain. Appropriate leaves were cleaned and dried in a convection

Table 1. Summary of Traditional leafy vegetables and their common uses (Hutchings et al., 1996).

\begin{tabular}{|c|c|c|c|c|c|}
\hline Scientific Name & Family Name & Common Name & $\begin{array}{l}\text { Traditional } \\
\text { Name }\end{array}$ & Common Uses & Source \\
\hline Amaranthus dubius & Amaranthaceae & Wild spinach & Terere & Potherb & Reservoir Hills, Durban, South Africa \\
\hline Amaranthus hybridus & Amaranthaceae & Cockscomb & Imbuya & Relish mixed with mealie meal & Reservoir Hills, Durban, South Africa \\
\hline Asystasia gangetica & Acanthaceae & Hunter's Spinach & * & Leaves edible & Reservoir Hills, Durban, South Africa \\
\hline Bidens pilosa & Asteraceae & Black Jack & Amalenjane & Used in tea & Reservoir Hills, Durban, South Africa \\
\hline Chenopodium album & Chenopodiaceae & Fat Hen & Imbikilicane & Eaten as porridge & Reservoir Hills, Durban, South Africa \\
\hline Ceratotheca triloba & Pedaliaceae & Wild Foxglove & Udonga & Cooked as spinach & Reservoir Hills, Durban, South Africa \\
\hline Emex australis & Polygonaceae & Devil's Thorn & Inkunzane & Cooked as spinach & Reservoir Hills, Durban, South Africa \\
\hline Galinsoga parviflora & Asteraceae & Gallant Soldier & Ushukeyana & Potherb & Reservoir Hills, Durban, South Africa \\
\hline Guilleminea densa & Amaranthaceae & Small Matweed & * & * & Reservoir Hills, Durban, South Africa \\
\hline Momordica balsamina & Cucurbitaceae & Balsam Apple & Inkaka & Cooked as spinach & Reservoir Hills, Durban, South Africa \\
\hline Oxygonum sinuatum & Polygonaceae & Stars Talk & Untabane & * & $\begin{array}{l}\text { National Botanical Institute, Durban, } \\
\text { South Africa }\end{array}$ \\
\hline Physalis Viscosa & Solanaceae & Grape Ground- Cherry & Uqadol & Fruit and berries edible & Park Rynie, South Africa \\
\hline Solanum nigrum & Solanaceae & Woody Nightshade & Isihlalakuhle & Cooked as a vegetable & Reservoir Hills, Durban, South Africa \\
\hline
\end{tabular}

${ }^{\star}$ Not recorded. 
oven for drying plant material at $60^{\circ} \mathrm{C}$ for a time period of $48 \mathrm{~h}$. The dried leaves were then processed, this was done in a blender by grinding the leaves to a fine powder. The processed leaves in powdered form were stored in air tight bottles until further use. All tests were done in triplicate.

\subsection{Processing on selected traditional South African leafy vegetables}

The ground plant material was boiled according to the cooking methods employed by (Shimelis \& Rakshit, 2007) with slight modifications by (Mosha \& Gaga, 1999), using a plant-to-distilled water ratio of $1: 4(\mathrm{w} / \mathrm{v})$ at $97^{\circ} \mathrm{C}$ for 5 and 15 minutes. The cooking water was drained off and the plant material was left to air dry for 24 hours. All cooking parameters were done in triplicate.

\subsection{Determination of tannins}

The Tannin content was determined by the Van-Buren and Robinson method. $50 \mathrm{~mL}$ of distilled water was added to $500 \mathrm{mg}$ sample and subjected to a mechanical shaker for 1 hour. The sample was then filtered into a $50 \mathrm{~mL}$ volumetric flask and made up in distilled water. $5 \mathrm{~mL}$ of the filtered sample was removed and mixed with $0.1 \mathrm{M} \mathrm{FeCl}_{3}$ in $0.1 \mathrm{~N} \mathrm{HCL}$ and $0.008 \mathrm{M}$ Potassium Ferrocyanide (Sigma-Aldrich P9387). The absorbance was read on a Spectrophotometer (Varian Cary 100 UV-Vis Spectrophotometer, USA) at $605 \mathrm{~nm}$ (Van-Buren \& Robinson, 1981).

\subsection{Determination of phytic acid}

The phytic acid content was established using a modified method by (Omotoso, 2006; Wheeler \& Ferrel, 1971). Phytic acid reacts with a coloured complex for example Fe (III)-sulphosalicylate, to form a colourless Fe (III)-phytate complex. The method measured the Fe (II) content which links to the phosphorus content (4:6) and the phosphorus content correlates to the phytic acid content (1:1). A standard curve was prepared using $\mathrm{Fe}\left(\mathrm{NO}_{3}\right)_{3}$ (Sigma-Aldrich F3002) in the range $0.025-2 \mathrm{mg} / \mathrm{mL}$. Five grams of ground sample was extracted in $50 \mathrm{~mL}$ of $3 \%$ Trichloroacetic acid (TAA) (Sigma-Aldrich T4885). The samples were placed in a shaking incubator (Labcon, USA) for 30 minutes at a constant speed of $156 \mathrm{rpm}$. The suspensions were thereafter centrifuged (Eppendorf 5810R, Germany) at $10000 \mathrm{rpm}$ for 15 minutes and the supernatants $(2.5 \mathrm{~mL}$ each) were transferred to $15 \mathrm{~mL}$ centrifuge tubes. Two millilitres of $\mathrm{FeCl} 3$ solution $(2 \mathrm{mg} / \mathrm{mL})$ was added to each sample. The sample was heated for 45 minutes in a water bath at a temperature of $90^{\circ} \mathrm{C}$. The solutions were centrifuged again (10 $000 \mathrm{rpm}$ for $15 \mathrm{~min}$ ) and the supernatants poured off. The pellets were washed by adding $10 \mathrm{~mL} 3 \%$ TAA solution, heated for 5 minutes and centrifuged (10 $000 \mathrm{rpm}$ for $15 \mathrm{~min}$ ). The resultant pellet was washed once with distilled water and re-suspended in $1 \mathrm{~mL}$ distilled water and $1.5 \mathrm{~mL}$ of $1.5 \mathrm{~N}$ $\mathrm{NaOH}$ (Sigma-Aldrich S5881) solution and stirred. The volume was brought up to $15 \mathrm{~mL}$ with distilled water, heated in boiling water for 30 minutes and centrifuged (10 $000 \mathrm{rpm}$ for $15 \mathrm{~min}$ ). The solution was filtered while hot (Whatman No. 2 filter paper). The precipitate was washed with $40 \mathrm{~mL}$ of hot distilled water and the filtrate discarded. The precipitate left in the paper was dissolved with $20 \mathrm{~mL} 3.2 \mathrm{~N}$ solution of $\mathrm{HNO} 3$ (Sigma-Aldrich) transferring it to a $50 \mathrm{~mL}$ volumetric flask. The sample was then cooled at room temperature and calibrated with distilled water. A $2.5 \mathrm{~mL}$ sample was transferred to a volumetric flask and diluted to $35 \mathrm{~mL}$ with $\mathrm{dH} 2 \mathrm{O}$. Thereafter $10 \mathrm{~mL}$ of $1.5 \mathrm{M}$ potassium thiocyanate $(\mathrm{KSCN})$ solution was added and the solution calibrated to $50 \mathrm{~mL}$ with distilled water. The absorbance of the samples were read within $1 \mathrm{~min}$ at an absorbance of $480 \mathrm{~nm}$ using a spectrophotometer (Varian Cary 100 UV-Vis Spectrophotometer, USA).

\subsection{Alkaloid precipitation}

The presence of alkaloids was established using a precipitation method by (Harborne, 1973; Edeoga et al., 2005) with slight modifications. Ammonium hydroxide was added to plant extracts in order to precipitate alkaloids. The dried sample was treated with $200 \mathrm{~mL}$ of $10 \%$ acetic acid in ethanol (v/v) for 4 hours at room temperature. The extract was thereafter filtered and concentrated to $50 \mathrm{~mL}$ on a rotary evaporator at a temperature of $60^{\circ} \mathrm{C} .1 \mathrm{~mL}$ of concentrated ammonium hydroxide was added drop wise to the extract until the precipitation was complete. The solution was left to stand in order for the precipitate to settle. The precipitate was collected and washed with a ratio of distilled water and ammonium hydroxide ( $5 \mathrm{~mL}: 5 \mathrm{~mL})(\mathrm{v} / \mathrm{v})$ and thereafter filtered. The remaining residue was dried at room temperature and weighed. The results were recorded in grams per $5 \mathrm{~g}$ dried leaves and converted to percentage.

\subsection{Quantification of oxalic acid}

The oxalic acid content was established using high performance liquid chromatography (HPLC) analysis with a modified method by (Miller \& Woodraw, 2004). A standard curve was used to establish the concentration of the unknown oxalic acid in the plant extracts. Oxalic acid standards were prepared in the range 1-20 $\mathrm{mg} / \mathrm{mL}$ and run chromatographed on an HPLC system (D7000 Lichrom Merck-Hitachi, Germany). The parameters included were a C18 column $(250 \mathrm{x} 4 \mathrm{~mm}$ id, particle size $5 \mu \mathrm{m}$ Luna $5 \mu \mathrm{C}-18$ (Phenomenex, USA) at room temperature, injection volume of $5 \mu \mathrm{l}$, mobile phase (80:20 HPLC grade methanol: $0.4 \%$ acetic acid $v / v$ ), flow rate of $1 \mathrm{~mL} / \mathrm{min}$, run time of $5 \mathrm{~min}$ and UV detection at $290 \mathrm{~nm}$. The retention time of oxalic acid under the above conditions should be approximately $1.4 \mathrm{~min}$. The mean absorbance units obtained with the standards were used to plot a standard curve. Oxalic acid was extracted from $0.5 \mathrm{~g}$ of dried leafy material using $4 \mathrm{~mL}$ of $0.025 \mathrm{M} \mathrm{HCL}$. The extract was centrifuged (Eppendorf 5810R, Germany) at $10000 \mathrm{rpm}$ for 20 minutes at a temperature of $25^{\circ} \mathrm{C}$. The supernatant was collected in $1 \mathrm{~mL}$ centrifuge tubes and passed through the Phenomenex C18 solid-phase extraction cartridge (Phenomenex, USA). The concentrations of oxalic acid in plant extracts were then calculated from the standard curve using the formula $\mathrm{y}=\mathrm{mx}+\mathrm{c}$.

\subsection{Quantification of cyanogenic glycoside}

Cyanogenic glycoside was determined using the alkaline picrate method of (Onwuka \& Olopade, 2005) with minor modifications. 2.5 grams of sample was dissolved in $25 \mathrm{~cm}^{3}$ 
distilled water. The cyanide extraction was left to stand overnight and then filtered (Inuwa et al., 2011). In order to prepare the cyanide standard curve, various concentrations of KCN solution containing 0.1 to $1.0 \mathrm{mg} / \mathrm{mL}$ cyanide were prepared. $4 \mathrm{~mL}$ of alkaline picrate solution ( $1 \mathrm{~g}$ of picrate and $5 \mathrm{~g}$ of $\mathrm{Na}_{2} \mathrm{CO}_{3}$ in $200 \mathrm{~cm}^{3}$ distilled water) was added to $1 \mathrm{~mL}$ of the sample filtrate and standard cyanide solution in test tubes and incubated in a water bath for 15 minutes. After colour was developed, the absorbance was read at $490 \mathrm{~nm}$ on a spectrophotometer (Varian Cary 100 UV-Vis Spectrophotometer, USA) with a blank consisting of $1 \mathrm{~mL}$ distilled water and $4 \mathrm{~cm}^{3}$ alkaline picrate solution. The cyanide content was extrapolated from the cyanide standard curve. The cyanogenic glycoside content was calculated as cyanogenic glycoside $(\mathrm{mg} / 100 \mathrm{~g})=($ concentration (mg) x 10/weight of sample). The concentration of cyanide was read off the graph.

\subsection{Statistical analysis}

All determinations were carried out in triplicate. Differences were evaluated by two-way analysis of variance, ANOVA (Graph Pad Prism), followed by Tukey test for multiple comparisons. Values are expressed as a mean \pm , standard deviation $(\mathrm{n}=3)$. Significance was accepted as $\mathrm{P}<0.05$.

\section{Results and discussion}

Tannins are identified as plant polyphenols that are capable of forming complexes with metal ions and macro-molecules like proteins and polysaccharides. Tannins have been known to adversely affect protein digestibility. Tannins usually form insoluble complexes with proteins and interfering with their bioavailability. Poor palatability is normally credited to diets that are high in tannins. Tannins are capable of leaving available protein by antagonistic competition and can therefore elicit a protein deficiency syndrome known in Sub-Saharan Africa as 'Kwashiorkor' (Bolanle et al., 2014). Tannins are responsible for a decrease in growth rate as well as a non-palatable taste. They also affect digestive enzymes (Soetan \& Oyewole, 2009). Tannin content at 0 minute processing ranged from $0,01 \mathrm{mg} / \mathrm{mL}$ to $0,14 \mathrm{mg} / \mathrm{mL}$. Solanum nigrum was found to contain the highest tannin concentration with a concentration of $0,14 \mathrm{mg} / \mathrm{mL}$. Amaranthus hybridus, Oxygonum sinuatum, Chenopodium album, Emex australis, Guilleminea densa and Galinsoga parviflora all contained tannins even though they were detected at a low concentration of less than $0,08 \mathrm{mg} / \mathrm{mL}$ (Figure 1). There was a significant difference in the tannin content between 0 and 5 minute boiling as well as between 0 and 15 minute boiling in Solanum nigrum as well as Bidens pilosa $(\mathrm{p}<0.0001)$ and Amaranthus dubius $(\mathrm{p}<0.05)$. There was no significant difference between 5 and 15 minute boiling in the decrease of tannin content. This indicated that a minimum of 5 minute boiling was adequate to reduce the tannin content in these three traditional leafy vegetables significantly. Although Physalis viscosa was high in tannin content at 0 minute boiling, there was no significant difference between 0 and 5 minute boiling but a significant difference between 0 and 15 minute boiling $(\mathrm{p}<0.0031)$. This indicates that Physalis viscosa required a minimum time period of 15 minute boiling in order to reduce its tannin content significantly (Table 2 ). The observations of a decrease in tannin content through boiling processes are in agreement with previous studies by (Singh et al., 2015). According to work done by (Akwaowo et al., 2000) boiling reduced tannin content by $3.6 \%$ in Eryngium foetidum.

Phytic acid (myo-inositol 1,2,3,4,5,6 hexakis-dihydrogen phosphate) or phytate is the major phosphorous storage compound in traditional leafy vegetables (Uusiku et al., 2010). Phytic acid has been recorded to inhibit the absorption of minerals and reduce the bioavailability of metal ions like zinc and iron as well as affect

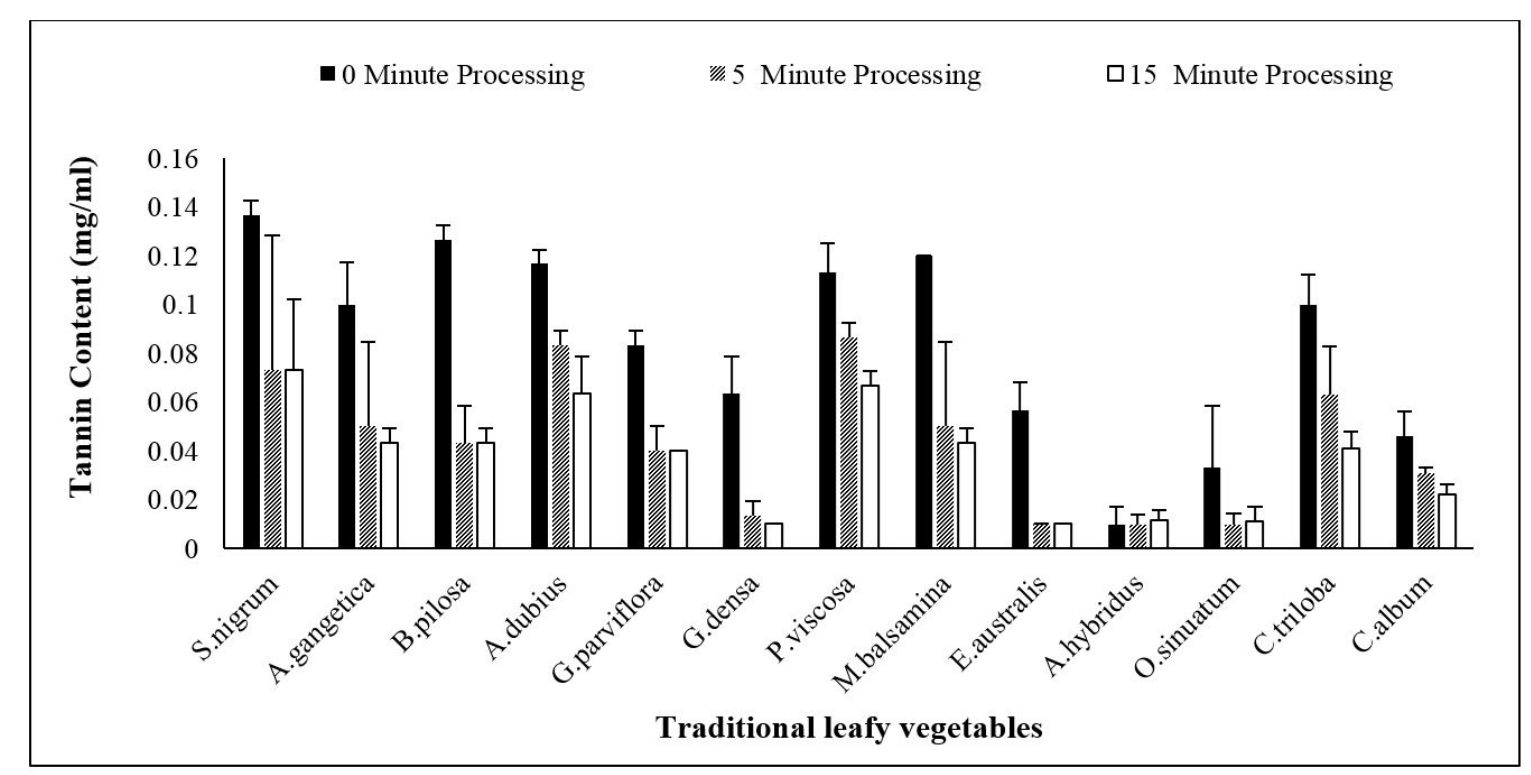

Figure 1. Effect of boiling on tannin concentration in 13 traditional leafy vegetables at 0,5 and 15 minute processing [Bars denote mean \pm standard deviation $(n=3)]$. 


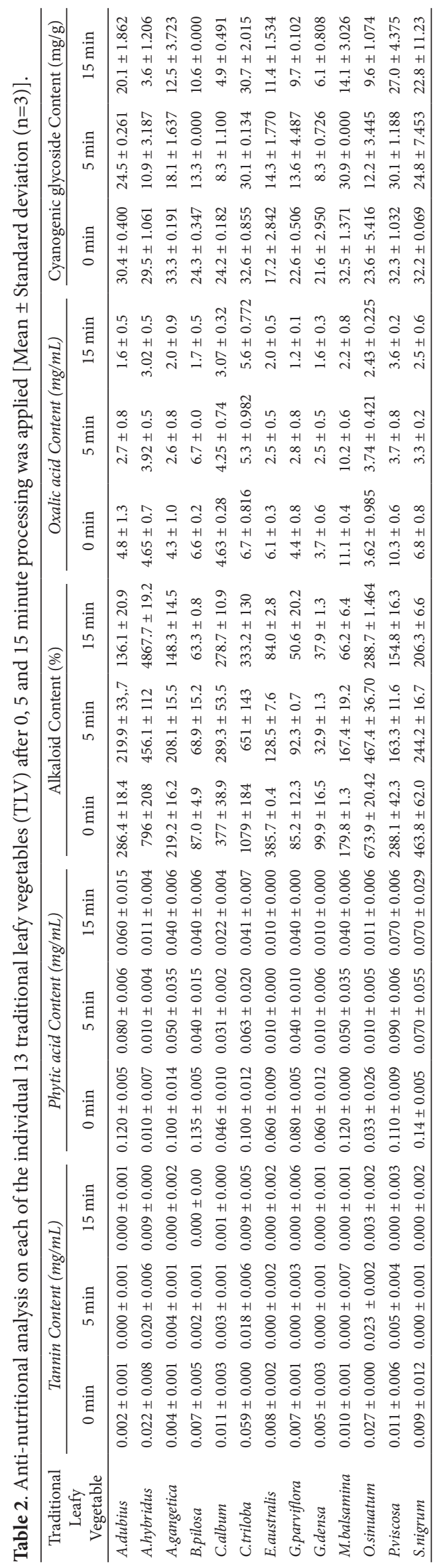


protein and starch digestion (Uusiku et al., 2010). A phytic acid intake of 4-9 $\mathrm{mg} / 100 \mathrm{~g}$ decreases iron absorption in humans by $4-5$ fold (Akwaowo et al., 2000). The phytic acid content at 0 minute processing varied between $0 \mathrm{mg} / \mathrm{mL}$ to $0,06 \mathrm{mg} / \mathrm{mL}$. All traditional leafy vegetables contained phytic acid less than $0,03 \mathrm{mg} / \mathrm{mL}$ except Ceratotheca triloba which contained the highest concentration of phytic acid with a concentration of $0,06 \mathrm{mg} / \mathrm{mL}$ at 0 minute processing. Amaranthus dubius contained the lowest phytic acid content of $0,002 \mathrm{mg} / \mathrm{mL}$. Ceratotheca triloba had the greatest decrease in phytic acid content after 5 minute boiling with a concentration of $0,06 \mathrm{mg} / \mathrm{mL}$ to $0,01 \mathrm{mg} / \mathrm{mL}$ (Figure 2). Due to the initial phytic acid concentration being minimal, there was no significant effect in the decrease of phytic acid between 0 and 5,5 and 15 or 0 and 15 minute boiling in 12 traditional leafy vegetables. Therefore 5 minute boiling was adequate to completely remove the phytic acid content in those 12 traditional leafy vegetables. Only Amaranthus hybridus attained a significant effect in the decrease of phytic acid content after 15 minute boiling. A total time of five minute boiling was adequate to eliminate the phytic acid content in Solanum nigrum, Momordica balsamina, Guilleminea densa, Galinsoga parviflora, Emex australis and Amaranthus dubius whereas Physalis viscosa and Asystasia gangetica required a total of fifteen minutes boiling to completely eliminate the phytic acid content (Table 2). The phytic acid concentration was minimal in all the leafy vegetables at 0 minute processing. This was consistent with work done by (Gupta et al., 2005). It is important to note, there was no significant difference in phytic acid between 5 and 15 minute boiling in all the leafy vegetables except for Amaranthus hybridus. Phytic acid was reported much lower than work done by (Akwaowo et al., 2000) on traditional leafy vegetables. According to similar work done by (Yadav \& Sehgal, 2003) cooking did not change the phytic acid content of leaves. The reason being could be that during cooking, endogenous phytases are inactivated by the heat and are broken down with high temperatures (Amalraj \& Pius, 2015). The interaction of the leaves with the hot water causes the cell wall to be ruptured and soluble phytic acid may leach into the medium which can account for phytic acid losses (Yadav \& Sehgal, 2003).

Alkaloids are a class of naturally containing organic nitrogen containing bases. Some common alkaloids include morphine and nicotine (Sood et al., 2012). Alkaloids are responsible for the bitterness in many traditional leafy vegetables. There are two groups of alkaloids, namely pyrrolizidine and quinolizidine. Pyrrolizidine are usually found in members of the Asteraceae family (Bidens pilosa and Galinsoga parviflora) which render these plants as toxic. Quinolizidines are more often found in Amaranthus species. Pyrrolizidines are not harmful on their own but become highly toxic when they are transformed by cytochrome P450 monooxygenases in the human liver (Uusiku et al., 2010). All 13 traditional leafy vegetables contained alkaloids ranging from 4 to $11 \%$. Physalis viscosa and Momordica balsamina contained the highest percentage of alkaloids of 10 and $11 \%$ respectively. Oxygonum sinuatum contained the lowest percentage of alkaloids of 3,62\% at 0 minute boiling (Figure 3 ). The traditional leafy vegetables that had a significant decrease in alkaloid content after 5 minute boiling were Bidens pilosa, Galinsoga parviflora, Physalis viscosa and Emex australis $(\mathrm{p}<0.0001)$. The remaining traditional leafy vegetables all required a total of 15 minute boiling to reduce the alkaloid content significantly to between $2 \%$ and 5, 6\% with the exception of Oxygonum sinuatum which had no significant difference in alkaloid decrease between all three boiling parameters (Table 2). The results of the current work are slightly lower than work reported by (Sood et al., 2012) which could have been due to varietal and agro-climatic conditions of the traditional leafy vegetables.

Oxalic acid exists in many traditional leafy vegetables and plant foods. Depending on species, oxalic acid/oxalate can occur as soluble salts of potassium and sodium or as insoluble salts of

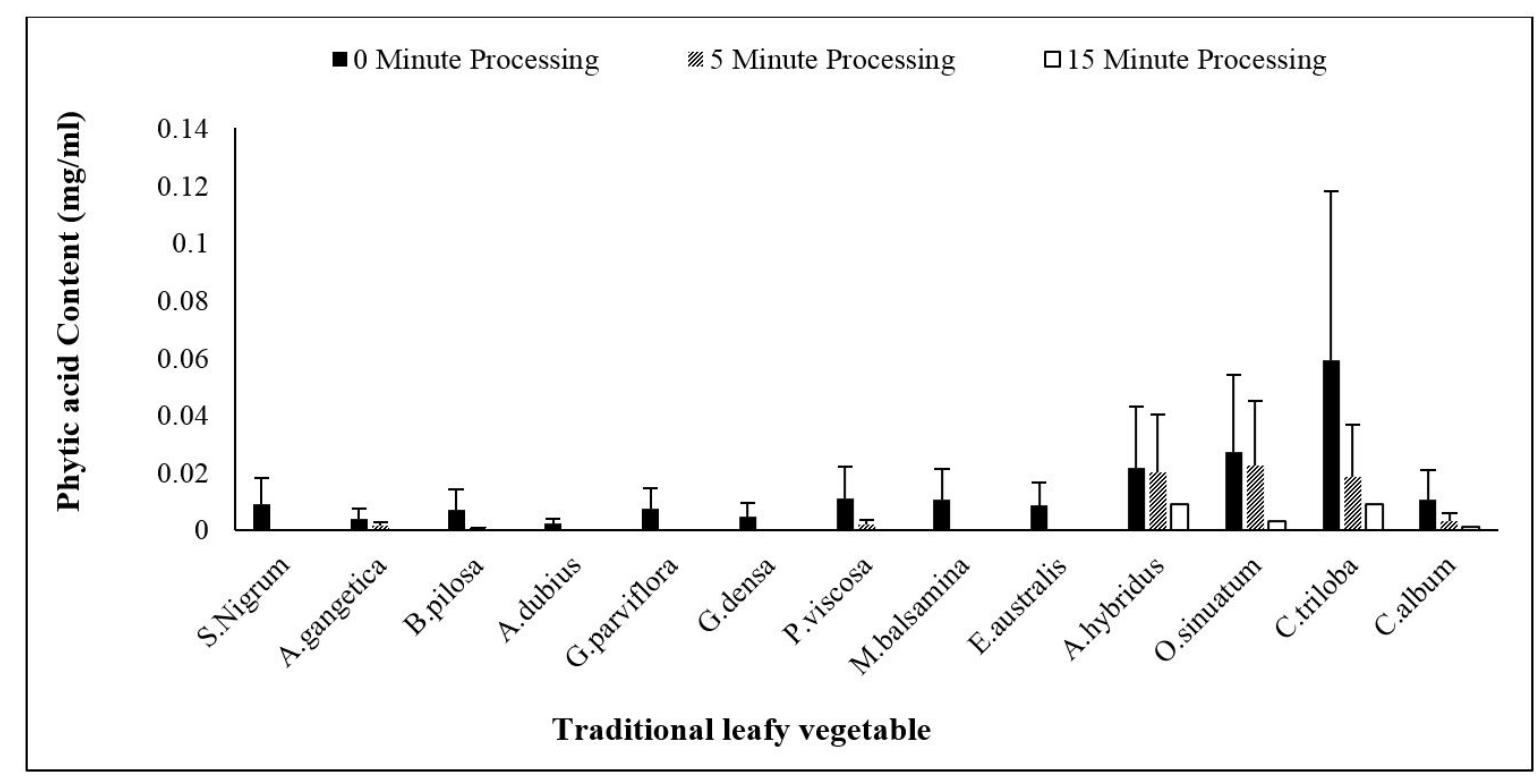

Figure 2. Effect of boiling on phytic acid concentration in 13 traditional leafy vegetables at 0,5 and 15 minute processing [Bars denote mean \pm standard deviation $(n=3)]$. 
calcium, magnesium or iron or it can occur as a combination of soluble and insoluble salts. Insoluble salts are excreted through faeces but soluble salts are absorbed by the body. This forms strong chelates with dietary calcium inhibiting its absorption. A high intake of this soluble oxalate can form kidney stones. Therefore, diets high in oxalic acid need supplementation of minerals to avoid deficiency (Uusiku et al., 2010). The oxalic acid content at 0 minute boiling ranged from $85 \mathrm{mg} / \mathrm{mL}$ to $1079 \mathrm{mg} / \mathrm{mL}$. All 13 traditional leafy vegetables contained oxalic acid with Ceratotheca triloba, Amaranthus hybridus and Oxygonum sinuatum having the highest concentrations of oxalic acid at 0 minute boiling. Galinsoga parviflora had the lowest concentration of oxalic acid of $85 \mathrm{mg} / \mathrm{mL}$. Other plants such as Bidens pilosa and Guilleminea densa also had concentrations lower than $100 \mathrm{mg} / \mathrm{mL}$ (Figure 4). The following plants were high in oxalic acid content and had no significant effect in the decrease of oxalic acid content with all boiling parameters namely Asystasia gangetica, Bidens pilosa, Galinsoga parviflora, Guilleminea densa, Physalis viscosa, Momordica balsamina and Chenopodium album. Solanum nigrum, Emex australis and Amaranthus hybridus. These leafy vegetables all required only 5 minute boiling to reduce their oxalic acid content significantly. Oxygonum sinuatum and Ceratotheca triloba had a significant effect in the decrease of oxalic acid content in all boiling parameters and responded the best to the processing. Ceratotheca triloba, Oxygonum sinuatum, Solanum nigrum and Emex australis had a significant difference in the decrease of

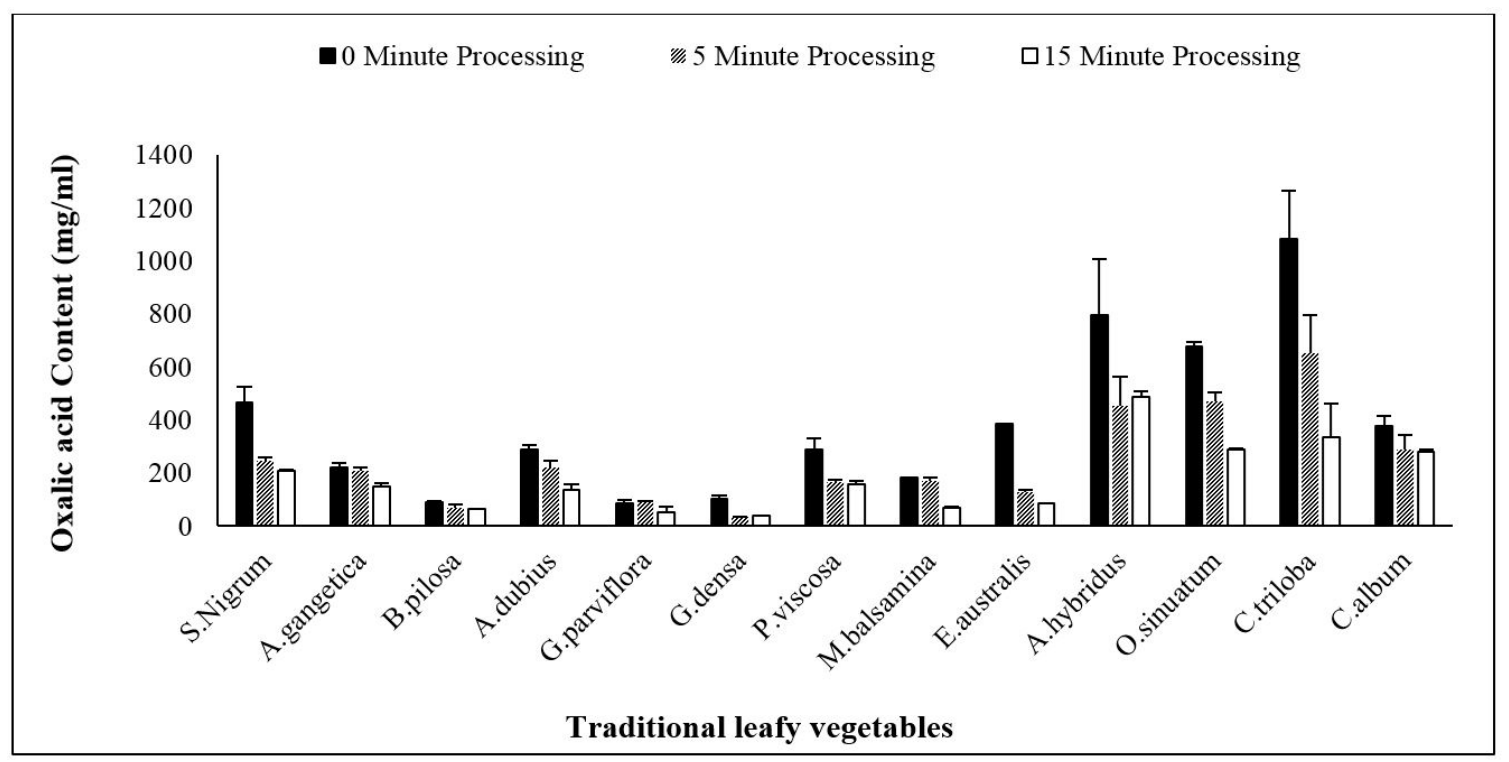

Figure 3. Effect of boiling on alkaloid percentage in 13 traditional leafy vegetables at 0,5 and 15 minute processing [Bars denote mean \pm standard deviation $(n=3)]$.

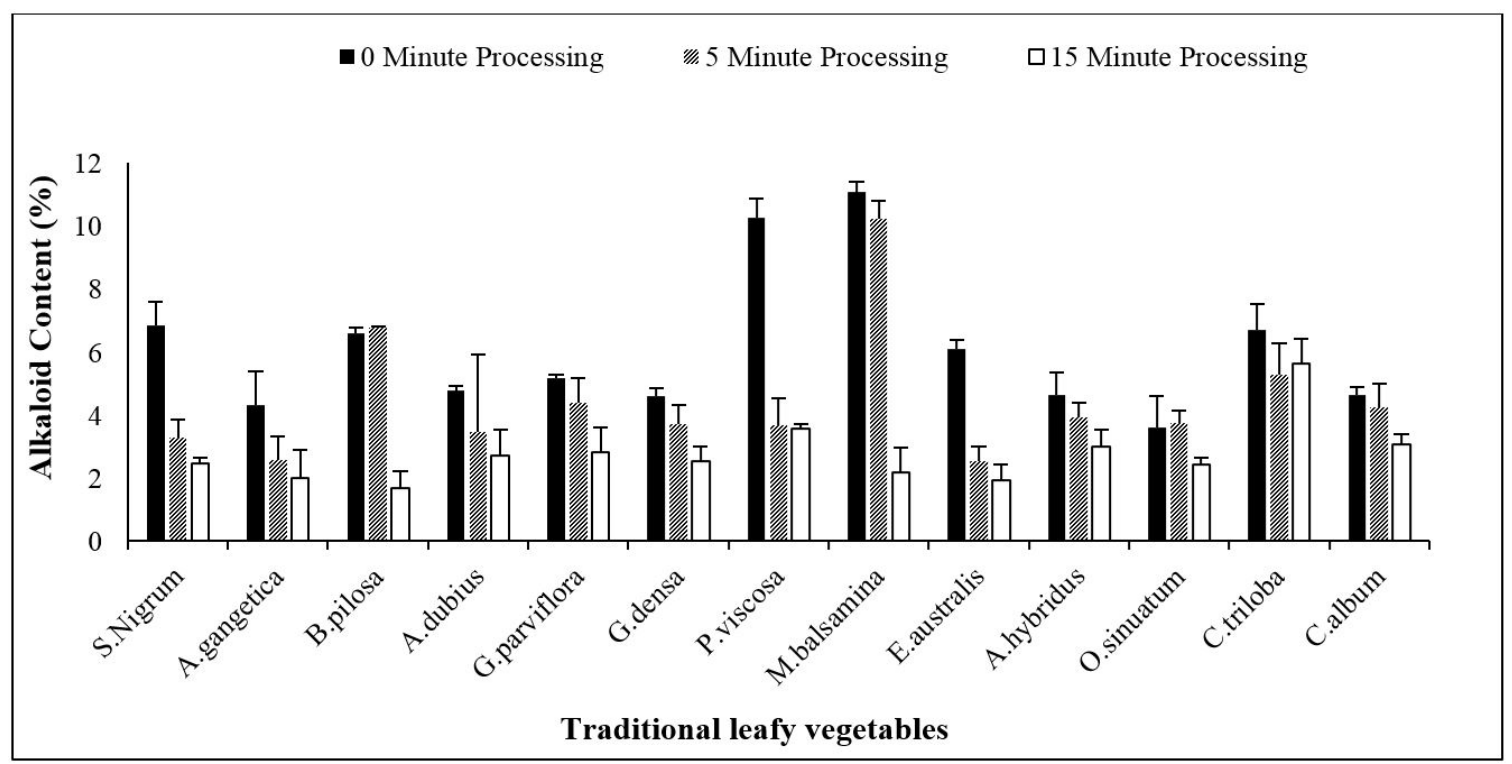

Figure 4. Effect of boiling on oxalic acid concentration in 13 traditional leafy vegetables at 0,5 and 15 minute processing [Bars denote mean \pm standard deviation $(n=3)]$. 


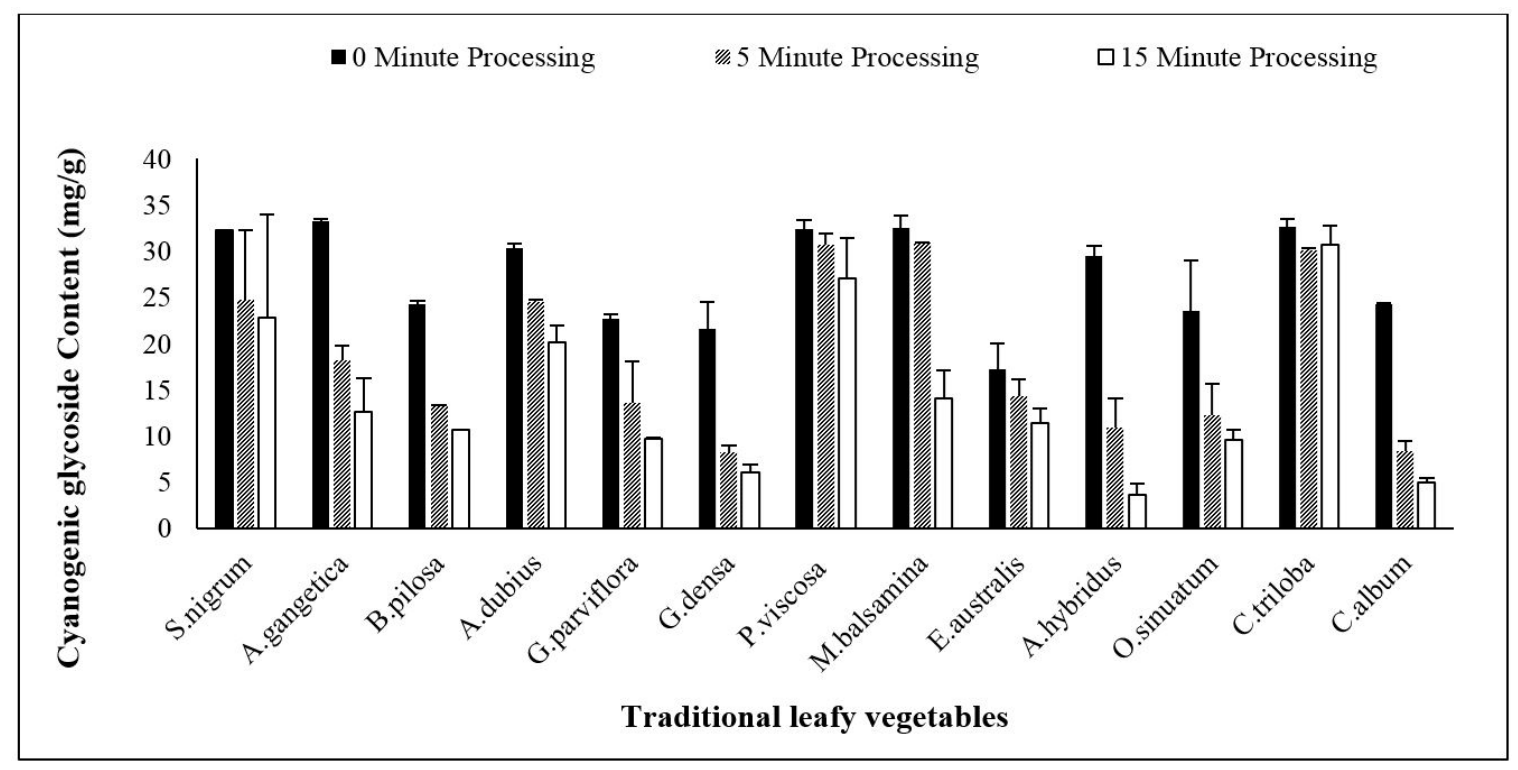

Figure 5. Effect of boiling on cyanogenic glycoside content in 13 traditional leafy vegetables at 0,5 and 15 minute processing [Bars denote mean \pm standard deviation $(n=3)]$.

oxalic acid content after a mere 5 minutes of boiling $(\mathrm{p}<0.0001)$. However, both Amaranthus species required a total of 15 minute boiling to attain a significant difference in its reduction of oxalic acid content. The oxalic acid contents were significantly lower in boiled leaves than fresh leaves. The decrease was highest in the leaves boiled at fifteen minutes (Table 2). Authors such as (Yadav \& Sehgal, 2003) have reported similar work. According to (Akwaowo et al., 2000), a daily intake of $450 \mathrm{mg}$ of oxalic acid has been reported to affect metabolism. Oxalic acid toxicity levels have been estimated at 2-5g/100g. These high levels of oxalic acid may reduce the bioavailability of metals like calcium. Ceratotheca triloba, Amaranthus hybridus and Oxygonum sinuatum were reduced to less than $450 \mathrm{mg}$ after 15 minutes of boiling. The oxalic acid content of raw leaves were significantly lower than that of boiled. The decrease was higher in the leaves boiled for a longer time period. This is in accordance to work done by (Yadav \& Sehgal, 2003) who reported loss of oxalate upon boiling. Oxalic acid content was also high in Amaranthus species according to work done by (Gupta et al., 2005). The results are also on par with work done by (Sood et al., 2012) in which the oxalic acid content of Chenopodium album cultivars were between 360-2000mg/100g.

Cyanogens, when hydrolyzed, produce toxic products such as hydrogen cyanide. Cyanide is a deadly poison with a lethal dose of $0.5-3 \mathrm{mg} / \mathrm{kg}$ body weight. This is because it has the ability to link with metals such as $\mathrm{Fe}^{2+}, \mathrm{Mn}^{2+}$ and $\mathrm{Cu}^{2+}$. These metals are functional groups of many enzymes which in turn inhibit processes such as, the reduction of oxygen in the cytochrome respiratory chain, electron chain transport in photosynthesis as well as the acting of enzymes like catalase and oxidase (Francisco \& Pinotti, 2000). All 13 plants contained cyanogenic glycoside at 0 minute processing in this study. Cyanogenic glycoside content at 0 processing ranged from 17 to $32 \mathrm{mg} / \mathrm{g}$ with Asystasia gangetica, Ceratotheca triloba, Physalis viscosa, Momordica balsamina and
Solanum nigrum attaining the highest cyanogenic glycoside contents at 0 minute boiling. Emex australis attained the lowest cyanogenic glycoside content of 17, $2 \mathrm{mg} / \mathrm{g}$ (Figure 5). All the traditional leafy vegetables had a significant difference in their decrease of cyanogenic glycoside content after a mere 5 minute processing with the exception of Physalis viscosa, Momordica balsamina, Emex australis and Ceratotheca triloba. Momordica balsamina had a significant difference in decrease of cyanogenic glycoside content after a 15 minute boiling period $(\mathrm{p}<0.0001)$. Physalis viscosa, Emex australis and Ceratotheca triloba had no significant difference in their decrease in cyanogenic glycoside content with neither 0,5 nor 15 minute processing. Therefore, a longer time period of boiling would be required to decrease the anti-nutrient content of these traditional leafy vegetables (Table 2). The toxic level of cyanide reported in foods is $35 \mathrm{~g} / 100 \mathrm{~g}$ (Akwaowo et al., 2000). The above leafy vegetables contained less than the toxic levels before and after processing. The results are in accordance to work done by (Sridhar \& Seena, 2006) on leguminous seeds in which it was proved that cyanide was reduced tremendously by processing methods such as boiling and soaking.

\section{Conclusion}

The anti-nutritional composition of traditional leafy vegetables revealed them to be a source of anti-nutrients. The study suggested that the boiling of leaves for a minimum of 5 and maximum of 15 minutes reduced the anti-nutritional factors significantly. The results of this study provide evidence that these local traditional vegetables could be important contributors to the high level of micronutrient malnutrition and could therefore be increasing the prevalence of chronic degenerative diseases amongst the population and can be eliminated through common boiling methods. The need for exploration of anti-nutritional information in traditional leafy 
vegetables is significant in overcoming nutritive disorders in order to contribute to health and nutritional security in Africa. Nutrient deficiency cannot be obtained by focusing on 5 anti-nutritional factors. It is recommended for further studies to be done on other anti-nutritional factors.

\section{Acknowledgements}

The author is grateful to the Levenstein Bursary and the National Research Foundation (NRF) for financial support (2015/2016)

\section{References}

Akwaowo, E. U., Ndon, B. A., \& Etuk, E. U. (2000). Minerals and antinutrients in fluted pumpkin (Telfairia occidentalis Hook $f$.). Food Chemistry, 70(2), 235-240. http://dx.doi.org/10.1016/S03088146(99)00207-1.

Amalraj, A., \& Pius, A. (2015). Bioavailability of calcium and its absorption inhibitors in raw and cooked green leafy vegetables commonly consumed in India: an in vitro study. Food Chemistry, 170, 430-436. PMid:25306367. http://dx.doi.org/10.1016/j.foodchem.2014.08.031.

Bolanle, A. O., Funmilola, A. S., \& Adedayo, A. (2014). Proximate analysis, mineral contents, amino acid composition, anti-nutrients and phytochemical screening of Brachystegia Eurycoma Harms and Pipper Guineense Schum and Thonn. American Journal of Food and Nutrition, 2. http://dx.doi.org/10.12691/ajfn-2-1-3.

Edeoga, H. O., Okwu, D. E., \& Mbaebie, B. O. (2005). Phytochemical constituents of some Nigerian medicinal plants. African Journal of Biotechnology, 4(7), 685-688. http://dx.doi.org/10.5897/AJB2005.0003127.

Embaby, H. E. (2010). Effect of soaking, dehulling, and cooking methods on certain antinutrients and in vitro protein digestibility of bitter and sweet lupin seeds. Food Science and Biotechnology. 19(4), 10551062. http://dx.doi.org/10.1007/s10068-010-0148-1

Francisco, I., \& Pinotti, M. H. P. (2000). Cyanogenic glycosides in plants. Brazilian Archives of Biology and Technology, 43(5), 487-492. http:// dx.doi.org/10.1590/S1516-89132000000500007.

Gupta, S., Jyothi Lakshmi, A., Manjunath, M. N., \& Prakash, J. (2005). Analysis of nutrient and antinutrient content of underutilized green leafy vegetables. Lebensmittel-Wissenschaft + Technologie, 38(4), 339-345. http://dx.doi.org/10.1016/j.lwt.2004.06.012.

Harborne, J. B. (1973). Phytochemical methods. London: Chapman and Hall Ltd.

Hutchings, A., Scott, A. H., Lewis, G., \& Cunningham, A. (1996). Zulu medicinal plants. South Africa: University of Natal Press.

Inuwa, H. M., Aina, V. O., Baba, G., Aimola, I., \& Amao, T. (2011). Comparative determination of antinutritional factors in groundnut oil and palm oil. Advance Journal of Food Science and Technology, 3, 275-279.

Lin, J.-T., Liu, S.-C., Shen, Y.-C., \& Yang, D.-J. (2011). Comparison of various preparation methods for determination of organic acids in fruit vinegars with a simple ion-exclusion liquid chromatography. Food Analytical Methods, 4(4), 531-539. http://dx.doi.org/10.1007/ s12161-011-9204-6.

Miller, R., \& Woodraw, I. (2004). Kakadu plum chemical analysis: cyanogens, alkaloids and oxalate. Melbourne: University of Melbourne.

Mosha, T. C., \& Gaga, H. E. (1999). Nutritive value and effect of blanching on the trypsin and chymotrypsin inhibitor activities of selected leafy vegetables. Plant Foods for Human Nutrition, 54(3), 271-283. PMid:10716408. http://dx.doi.org/10.1023/A:1008157508445.

Odhav, B., Beekrum, S., Akula, U., \& Baijnath, H. (2007). Preliminary assessment of nutritional value of traditional leafy vegetables in KwaZulu-Natal, South Africa. Journal of Food Composition and Analysis, 20(5), 430-435. http://dx.doi.org/10.1016/j.jfca.2006.04.015.

Olawoye, B. T., Gbadamosi, S. O., \& Yildiz, F. (2017). Effect of different treatments on in vitro protein digestibility, antinutrients, antioxidant properties and mineral composition of Amaranthus viridis seed. Journal of Cogent Food \& Agriculture, 3, 1296402. http://dx.doi. org/10.1080/23311932.

Omotoso, O. T. (2006). Nutritional quality, functional properties and anti-nutrient compositions of the larva of Cirina forda (Westwood) (Lepidoptera: Saturniidae). Journal of Zhejiang University Science B, 7(1), 51-55. http://dx.doi.org/10.1631/jzus.2006.B0051.

Onwuka, S. K., \& Olopade, J. O. (2005). Some aspects of the clinical anatomy of the mandibular and maxillofacial Regions of the West African dwarf goat in Nigeria. International Journal of Morphology, 23, 33-36. http://dx.doi.org/10.4067/S0717-95022005000100006.

Raes, K., Knockaert, D., Struijs, K., \& Van Camp, J. (2014). Role of processing on bioaccessibility of minerals: Influence of localization of minerals and anti-nutritional factors in the plant. Trends in Food Science \& Technology, 37(1), 32-41. http://dx.doi.org/10.1016/j. tifs.2014.02.002.

Shimelis, E. A., \& Rakshit, S. K. (2007). Effect of processing on antinutrients and in vitro protein digestibility of kidney bean (Phaseolus vulgaris L.) varieties grown in East Africa. Food Chemistry, 103(1), 161-172. http://dx.doi.org/10.1016/j.foodchem.2006.08.005.

Singh, S., Swain, S., Singh, D. R., Salim, K. M., Nayak, D., \& Roy, S. D. (2015). Changes in phytochemicals, anti-nutrients and antioxidant activity in leafy vegetables by microwave boiling with normal and $5 \% \mathrm{NaCl}$ solution. Food Chemistry, 176, 244-253. PMid:25624230. http://dx.doi.org/10.1016/j.foodchem.2014.12.068.

Soetan, K. O., \& Oyewole, O. E. (2009). The need for adequate processing to reduce the antinutritional factors in plants used as human foods and animal feeds. African Journal of Food Science, 3(9), 223-232.

Sood, P., Modgil, R., Sood, M., \& Chuhan, P. K. (2012). Anti-nutrient profile of different chenopodium cultivars leaves. Annals. Food Science and Technology, 13(1), 68-74.

Sridhar, K. R., \& Seena, S. (2006). Nutritional and antinutritional significance of four unconventional legumes of the genus Canavalia: a comparative study. Food Chemistry, 99(2), 267-288. http://dx.doi. org/10.1016/j.foodchem.2005.07.049.

Ugwu, F. M., \& Oranye, N. A. (2006). Effects of some processing methods on the toxic components of African breadfruit (Treculia africana). African Journal of Biotechnology, 5(22), 2329-2333. http://dx.doi. org/10.5897/AJB06.382.

Unuofin, J. O., Otunola, G. A., \& Afolayan, A. J. (2017). Nutritional evaluation of Kedrostis africana (L.) Cogn: An edible wild plant of South Africa. Asian Pacific Journal of Tropical Biomedicine, 7(5), 443-449. http://dx.doi.org/10.1016/j.apjtb.2017.01.016.

Uusiku, N. P., Oelofse, A., Duodu, K. G., Bester, M. J., \& Faber, M. (2010). Nutritional value of leafy vegetables of sub-Saharan Africa and their potential contribution to human health: a review. Journal of Food Composition and Analysis, 23(6), 499-509. http://dx.doi. org/10.1016/j.jfca.2010.05.002.

Van-Buren, T. P., \& Robinson, W. C. (1981). Formation of complexes between protein and tannin acid. Agriculture. Food Chemistry, 1. http://dx.doi.org/10.1021/jf60164a003.

Velisek, J. (2014). The Chemistry of Food, Nova Jersey: Wiley-Blackwell. 
Wheeler, E. L., \& Ferrel, R. E. (1971). A method for phytic acid determination in wheat and wheat fractions. Cereal Chemistry, 48, 312-316.

World Health Organization - WHO. (1982). Some of the common nutritional problems in South Africa. Genebra: WHO.
Yadav, S. K., \& Sehgal, S. (2003). Effect of domestic processing and cooking on selected antinutrient contents of some green leafy vegetables. Plant Foods for Human Nutrition, 58(3), 1-11 http:// dx.doi.org/10.1023/B:QUAL.0000040359.40043.4f. 